\title{
Some phenotypic and genotypic characteristics of prevailing gonococcal strains in northern Norway
}

\author{
EDVARD S FALK,* BJARNE BJORVATN, $\dagger$ BJØRN - ERIK KRISTIANSEN, $\dagger$ \\ BIRGER SøRENSEN, $\uparrow$ KJETIL MELBY $\uparrow$ AND DAN DANIELSSON $\ddagger$
}

From the Departments of ${ }^{*}$ Dermatology and $\nmid$ Medical Microbiology, University Hospital, Troms $\varnothing$, Norway, and the ${ }^{*}$ Department of Clinical Microbiology and Immunology, Örebro Medical Center Hospital, Örebro, Sweden

SUMMARY Ninety two non-penicillinase producing Neisseria gonorrhoeae (non-PPNG) strains were investigated by the restriction enzyme technique with Hind III enzyme. Serogrouping by coenzyme A with monoclonal antibodies and testing susceptibility to doxycycline were also performed by an agar dilution method. Fifteen different restriction enzyme patterns were shown, of which three represented $50 \%$ (46/92) of all strains. One band, representing a deoxyribonucleic acid (DNA) fragment of 1.45 kilobase pairs, was shared by all the strains investigated. Serogroup WI dominated, representing 57 isolates $(62 \%)$ with four serovars, one of which was found in $82 \%$ (47/57) of the WI serogroups. Eight serovars were found among WII and WIII serogroups, but no one serovar dominated, as happened among WI serogroups. Identical serovars and restriction enzyme patterns were found in eight patients who were epidemiologically linked. All strains were highly or moderately sensitive to doxycycline, and the strains belonging to serogroup WI were more sensitive than those in the WII or WIII serogroups.

\section{Introduction}

We have previously described the use of the restriction enzyme technique to characterise the genomic organisation of Neisseria gonorrhoeae. ${ }^{1-3}$ The restriction pattern (genomic fingerprint) of individual gonococcal strains appears to be stable and highly specific. ${ }^{1}$ In fact, the restriction enzyme technique not only differentiates between strains that by phenotyping belong to different groups and types, but may even detect subtle differences between isolates that are completely identical by the coenzyme $\mathbf{A}$ technique using monoclonal antibodies.

Though previous studies included small numbers of partly selected strains, several different genotypes of gonococci were discovered. ${ }^{1-3}$ Similar studies with the closely related $N$ meningitidis have shown an interesting correlation between genomic organisation and virulence. ${ }^{4}$ Thus among the wide variety of restriction patterns represented by the prevailing B15 meningococci, only one very homogeneous set of patterns appears to be linked with invasive disease.

Address for reprints: Dr Edvard S Falk, Department of Dermatology, University Hospital, 9012 Troms $\varnothing$, Norway

Accepted for publication 9 May 1985
As in the case of meningococcal infection, northern Norway at present has a considerably higher incidence of gonorrhoea than the average for the country. ${ }^{5}$ Even in gonococcal infection the clinical range may, at least in part, depend on bacterial rather than host factors. The ultimate goal of our investigations, therefore, was to correlate individual restriction patterns and serovars with the clinical outcome of the respective infection.

The material studied in the present report consisted of almost all gonococcal isolates obtained from patients in the city of Troms $\varnothing$ and the nearby surroundings (an area containing about 70000 inhabitants) during three months. The specific aim of this study was to define the genotypic and phenotypic heterogeneity of clinical isolates of $\mathbf{N}$ gonorrhoeae in this region of northern Norway.

Patients, materials, and methods

GONOCOCCAL STRAINS

The material comprised 92 isolates of nonpenicillinase producing $N$ gonorrhoeae (non-PPNG) strains that were recovered in our routine laboratory from 92 patients (53 women and 39 men) in the 
Troms $\varnothing$ area during the months June to August 1983. We based estimations of the representativity of the material on comparison with official morbidity statistics.

We collected bacterial specimens from the cervix of all 53 women and from the urethra of all 39 men with charcoal swabs, which were transported to the laboratory on Stuart's medium.

We used gonococcal agar medium prepared from GC agar medium base (BBL Microbiology Systems, Cockeysville, Maryland, United States of America) with Bacto haemoglobin and IsoVitalex and without antibiotics for isolation as well as subculture. Identification of species followed standard laboratory procedure. After being subcultured the strains were either submitted directly to further analysis or frozen at $-70^{\circ} \mathrm{C}$ in brain and heart infusion broth supplemented with $10 \%$ glycerol until required.

\section{RESTRICTION ENDONUCLEASE FINGERPRINTING}

The procedure for restriction enzyme fingerprinting has been described previously. ${ }^{1}$ In short, bacteria were grown overnight on the gonococcal (GC) medium without antibiotics. One colony was further subcultivated under the same conditions. Bacteria were then harvested and lysed by the addition of ethylenediamenetetra-acetic acid (EDTA), lysozyme, ribonuclease, pronase, and Triton X-100. Deoxyribonucleic acid (DNA) was extracted by repeated treatment with chloroform and phenol and was dialysed against a DNA buffer to an average concentration of $600-1500 \mathrm{mg} / \mathrm{l}$. The DNA was then digested by the restriction enzyme, endonuclease Hind III, as described by the manufacturer (Amersham, England). We separated the resulting DNA fragments electrophoretically in a $4 \%$ polyacrylamide gel which was run for 20 hours at $10^{\circ} \mathrm{C}$ with a constant current of $40 \mathrm{~mA}$. DNA from the Escherichia coli phage P4, whose molecular weight is 11.3 kilobase pairs, digested by Hind III was used as a fragment size marker. ${ }^{6}$ The gel was stained with ethidium bromide, washed, and photographed in ultraviolet light. The different band patterns (genomic fingerprints) were compared visually.

We also scanned the individual restriction patterns in gel with a Joyce-Loebl microdensitometer. The experimental conditions were rigorously standardised to secure comparable patterns. Every electrophoretic run included several lanes for the well defined fragments of phage P4 DNA digested by Hind III to ensure comparability between different parts of the gel.

SEROLOGICAL CLASSIFICATION

We serogrouped the gonococcal strains by coenzyme A with monoclonal antibodies against protein IA (serogroup WI) and protein IB (serogroups WII or III) antigens. $^{7-9}$ Each strain was tested by coenzyme $\mathbf{A}$ against a set of six antibodies specific to protein IA (designated 4G5 (e), 2F12 (d), 6D9 (g), 5C2 (k), 5G9 (i), and 5D1 (h)) and seven antibodies specific to protein IB (3C8 (a), 2D6 (c), 2H7 (e), 2G2 (g), 2D4 (h), $3 \mathrm{~B} 10(\mathrm{j})$, and $2 \mathrm{H1}(\mathrm{k}))$. The serogroup and serovar of $\mathrm{a}$ particular strain was written according to reactivity for example, IA/edih, IB/acjk, etc - as proposed by Sandström et al, unpublished observation). (The monoclonal antibodies were a gift from Dr M Tam, Genetic System Corporation, Seattle, United States of America, and the staphylococci containing protein A were a gift from Dr L Rudin, Pharmacia, Uppsala, Sweden).

\section{ANTIBIOTIC SENSITIVITY TESTING}

We tested sensitivity to antibiotic by an agar dilution method"l using gonococcus agar base (Oxoid, England) containing various concentrations $(0.03$ $\mathrm{mg} / 1$ to $16 \mathrm{mg} / \mathrm{l}$ ) of doxycycline (Pfizer, New York, USA). We transferred $10^{7}$ colony forming units (cfu) from a fresh culture of the strains to the agar surface with a multipoint inoculator (Mast Laboratories, Liverpool, England). The minimum inhibitory concentration (MIC) was defined as the lowest concentration that completely suppressed bacterial growth.

\section{Results}

Table I shows the age and sex of the patients. The dominance of patients aged under $25(67 \%)$ and the high percentage of women aged 15-19 (29\% of all patients) agree with the official morbidity statistics for the region. ${ }^{5}$ The number of strains recovered exceeded the number of officially recorded cases of gonorrhoea by a factor of about $\mathbf{1 \cdot 3}$. The recovery rates during the period of observation were close to the monthly average for 1983 .

The fingerprints (restriction patterns) obtained with the restriction enzyme method consisted of 40-45 bands, whose size ranged from 0.8 to 5 kilobase pairs. Many of the isolates disclosed identical restriction patterns, and only minor differences were discernable between others. Table II and fig 1 show that 15 different restriction enzyme patterns (tentatively designated I-XV) were detected among the 92 isolates.

TABLE I Age and sex of 92 patients with uncomplicated gonorrhoea

\begin{tabular}{lcl}
\hline $\begin{array}{l}\text { Age } \\
\text { (years) }\end{array}$ & $\begin{array}{l}\text { Men } \\
(n=39)\end{array}$ & $\begin{array}{l}\text { Women } \\
(n=53)\end{array}$ \\
\hline $15-19$ & 8 & 27 \\
$20-24$ & 15 & 12 \\
$25-29$ & 8 & 7 \\
$30-34$ & 5 & 5 \\
$35-49$ & 3 & 2 \\
\hline
\end{tabular}




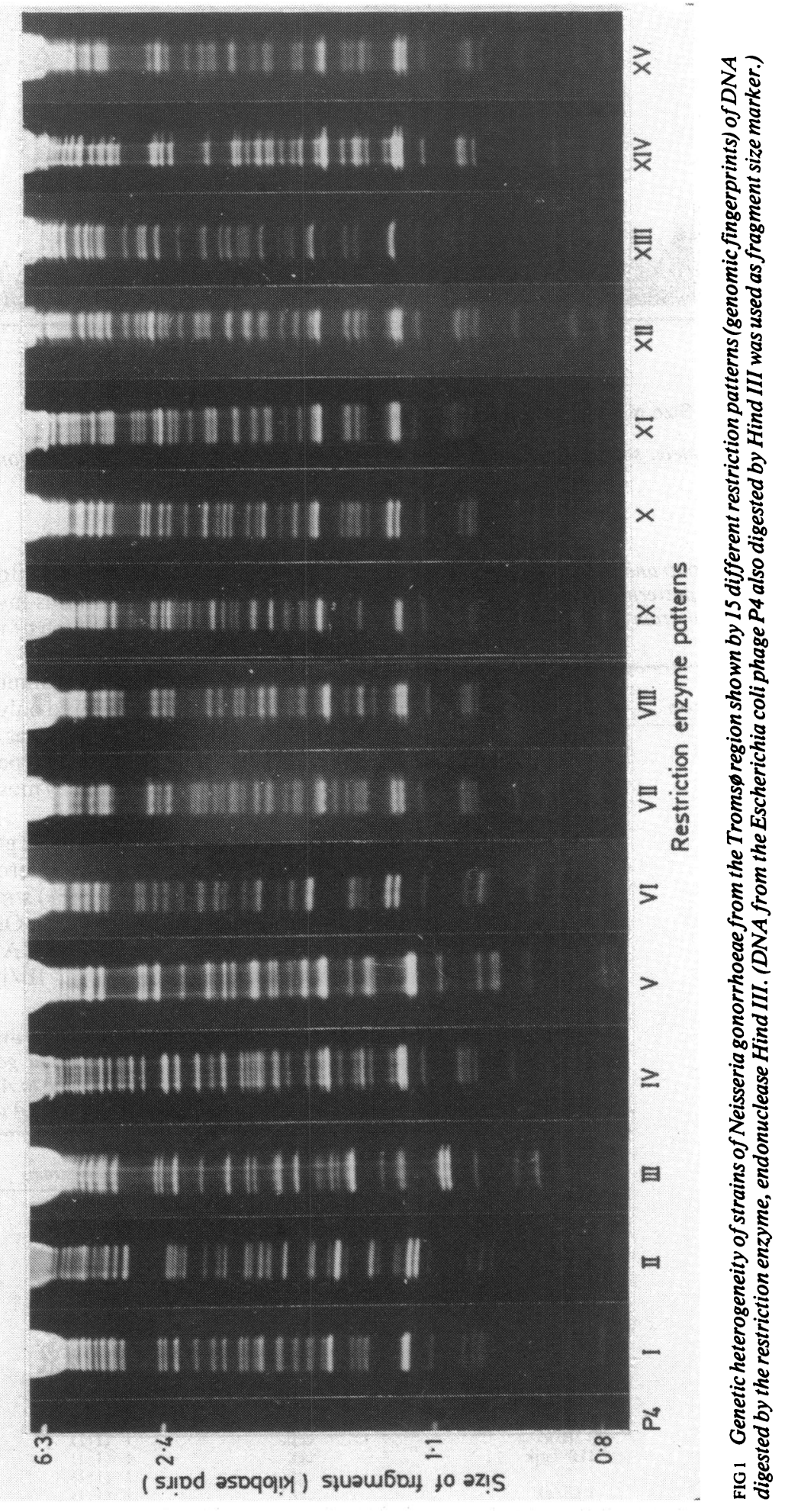




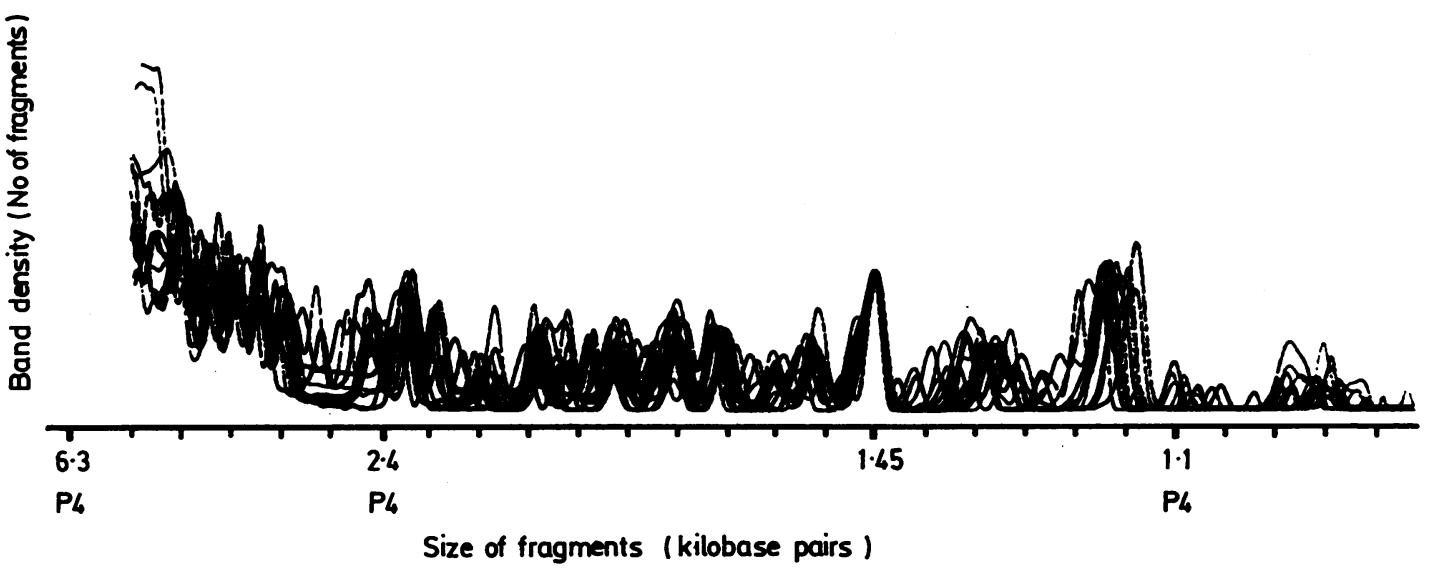

FIG 2 Superimposed microdensitometer scanning of 15 individual restriction patterns of strains of Neisseria gonorrhoeae from the Tromsø region.

TABLE II Relation between serogroup and serovar patterns and DNA restriction enzyme patterns (provisionally numbered I to $X V$ ) of 92 gonococcal strains from the Troms region

\begin{tabular}{|c|c|c|}
\hline $\begin{array}{l}\text { Restriction } \\
\text { enzyme pattern }\end{array}$ & $\begin{array}{l}\text { No of strains } \\
\text { within each pattern }\end{array}$ & $\begin{array}{l}\text { Serogroup/ } \\
\text { serovar patterns }\end{array}$ \\
\hline I & 18 & $\begin{array}{l}15 \text { IAVedgkih } \\
2 \text { IA/edgk } \\
1 \text { IB/acej }\end{array}$ \\
\hline II & 16 & $\begin{array}{l}14 \text { IA/edgkih } \\
2 \text { IA/edgk }\end{array}$ \\
\hline III & 12 & $\begin{array}{l}10 \text { IA/edgkih } \\
2 \text { IA/edgk }\end{array}$ \\
\hline IV & 1 & 1 IA/edgkih \\
\hline $\mathbf{v}$ & 1 & 1 IA/edgkih \\
\hline VI & 6 & $\begin{array}{l}4 \text { IA/edgkih } \\
2 \text { IA/edgk }\end{array}$ \\
\hline VII & 1 & $1 \mathrm{IA} /$ edih \\
\hline VIII & 1 & $1 \mathrm{IA} / \mathrm{gk}-\mathrm{IB} / \mathrm{j}$ \\
\hline IX & 7 & $\begin{array}{l}5 \mathrm{IB} / \text { acej } \\
2 \mathrm{IB} / \mathrm{ajk}\end{array}$ \\
\hline $\mathbf{x}$ & 8 & $8 \mathrm{IB} /$ acejk \\
\hline XI & 6 & $\begin{array}{l}2 \mathrm{IA} / \text { edgkih } \\
3 \mathrm{IB} / \text { acej } \\
1 \mathrm{IB} / \mathrm{cek}\end{array}$ \\
\hline XII & 5 & $\begin{array}{l}2 \mathrm{IB} / \text { acej } \\
2 \mathrm{IB} / \text { ajk } \\
1 \mathrm{IB} / \text { cejk }\end{array}$ \\
\hline XIII & 5 & $\begin{array}{l}4 \mathrm{IB} / \text { ajk } \\
1 \mathrm{IB} / \mathrm{cgk}\end{array}$ \\
\hline XIV & 4 & $\begin{array}{l}3 \mathrm{IB} / \mathrm{ak} \\
1 \mathrm{IB} / \mathrm{cgjk}\end{array}$ \\
\hline XV & 1 & $1 \mathrm{IB} / \mathrm{ak}$ \\
\hline
\end{tabular}

The band patterns I, II, and III dominated, representing 50\% (46/92) of all strains investigated. Only one strain was represented in each of the groups IV, V, VII, VIII, and X.

Superimposed microdensitometer scanning of these 15 different restriction patterns showed only one band (fragment size 1.45 kilobase pair) that was shared by all the clones (fig 2). Many of the bands (peaks in the figure), however, were clearly shared by most of the 15 genetic variants represented.

Table III shows that $57(62 \%)$ of the 92 gonococcal isolates belonged to the protein IA (WI) serogroup, as identified by coenzyme $A$, and $35(38 \%)$ strains to the protein IB serogroup (WII or WIII). One strain, however, reacted both with protein IA (serovar IA/gk) and with protein IB (serovar IB/j). The 57

TABLE III Distribution into serogroup and serovar patterns of 92 non-pencillinase producing Neisseria gonorrhoeae strains from the Troms region during June to August 1983 using monoclonal antibodies against protein IA and IB

\begin{tabular}{llll}
\hline Serogroup & $\begin{array}{l}\text { Specific monoclonal } \\
\text { antibodies against }\end{array}$ & $\begin{array}{l}\text { No }(\%) \text { of } \\
\text { reacting strains }\end{array}$ & Comments \\
\hline WI & $\begin{array}{l}\text { Protein IA: } \\
\text { edgkih }\end{array}$ & $47(51 \cdot 1)$ & \\
& edgk & $8(8 \cdot 7)$ & \\
edih & $1(1 \cdot 1)$ & Strain also \\
gk & $1(1 \cdot 1)$ & reacted with \\
& & & \\
protein IB/j
\end{tabular}


strains of the protein IA (WI) serogroup belonged to one of four different serovars, one of which (IA/edgkih) dominated, being found in $47(82 \%)$ of the strains. The protein IB (WII or WIII) serogroup was more heterogeneous as the 35 strains in this serogroup belonged to one of eight different serovars, none of which dominated.

As can be seen in table II, 15 of 18 strains of pattern I, 14 of 16 strains of pattern II, 10 of 12 strains of pattern III, and four of six strains of pattern VI had the serovar pattern IA/edgkih. Moreover, all eight strains of pattern $X$ had the serovar pattern IB/acejk. It was also obvious that some of the strains with the same serovar pattern had different restriction enzyme band patterns.

Six patients from whom the strains in pattern $\mathrm{X}$ were isolated were epidemiologically linked, and the two other patients with this pattern were also a contact pair. No link between these two and the six patients was, however, known.

The MICs of doxycycline for the 92 strains ranged from $0.031 \mathrm{mg} / 1$ to $4 \mathrm{mg} / \mathrm{l}$. Of the 57 with serological markers for WI, $29(51 \%)$ had MICs of $\leqslant 0.25 \mathrm{mg} / \mathrm{l}$, whereas $29(83 \%)$ of the 35 with markers for WII or WIII had MICs of $\geqslant 0.5 \mathrm{mg} / \mathrm{l}$. No strain was highly resistant (MIC $\geqslant 8 \mathrm{mg} / \mathrm{l}$ ) to doxycycline.

\section{Discussion}

We have shown previously that the restriction enzyme technique may differentiate between strains that by modern phenotypic classification appear to be identical. ${ }^{1-3}$ Previous experience also indicates that the individual restriction patterns are stable in vitro as well as in vivo. ${ }^{1}$ Thus there were no changes in the restriction enzyme pattern of one gonococcal strain after 41 passages in vitro in six weeks. The various virulent and non-virulent variants of colony morphology of a particular gonococcal strain also showed the same band pattern. ${ }^{1}$ Furthermore, the genetic stability has been shown by identical restriction enzyme patterns of one B15 meningococcal strain after 29 passages in vitro in four weeks. ${ }^{11}$ Another B15 meningococcal strain that was followed from the time of acquisition (in the throat) through an episode of septicaemia (in the blood) and subsequently for 13 months as a carrier strain (in the throat) showed completely identical restriction enzyme patterns throughout the period of observation. ${ }^{11}$

The possibility of several gonococcal clones coexisting in the same person has not been investigated. In practice phenotypically similar, but genotypically differing, isolates would only be detectable if represented by a considerable percentage of the total gonococcal population. Experience from meningococcal studies, particularly the finding of genetic identity in isolates recovered from different sites (throat, blood, and cerebrospinal fluid) of the same patients, ${ }^{12}$ as well as the completely identical isolates from one person over a period of 13 months, ${ }^{11}$ do not provide support for the multiclonal concept. Stability of the individual clonal pattern combined with the potential for detecting even subtle genetic differences make the restriction enzyme technique useful for epidemiological investigations of communicable diseases, such as gonorrhoea, particularly when combined with coenzyme A to show serological markers. ${ }^{7}$

The material studied in the present report (including age and sex distribution of the patients), which appears to be representative of gonococcal disease in our region, shows the wide variety of clones that may operate simultaneously within a small epidemiological area. The heterogeneity of these strains is further shown by phenotypic classification by serology and also by antibiotic sensitivity testing. Not unexpectedly, the number of cases reported was smaller than the number of gonococcal isolates recovered. Unfortunately, we did not have the clinical data connected with the individual isolates. Hence, the interesting aspect of correlating restriction patterns and phenotypic characteristics with clinical features of the infection must await future studies.

In this study we found 15 different restriction enzyme patterns and 12 serovars among the 92 strains investigated. As shown in previous studies, gonococcal strains with the same restriction enzyme pattern could belong to different serovars or vice versa. ${ }^{1-3}$ Interestingly, none of the penicillinase producing strains of $N$ gonorrhoeae (PPNG) in a previous study ${ }^{2}$ showed the same restriction enzyme band pattern as any non-PPNG strain in the study reported here, even if they had identical serovars. This lack of correlation between a particular restriction enzyme pattern and a serovar enhances the heterogeneity of gonococcal strains even more. The same serovar pattern was found in 47 strains, however, and although this serovar pattern was represented in seven restriction enzyme patterns, several strains in each group had identical restriction enzyme and serovar patterns. As previous studies have shown that strains with epidemiological links may have identical restriction enzyme and serovar patterns, ${ }^{1-3}$ we assume that many strains with common genomic and serovar patterns are epidemiologically linked, as we know was the case for restriction enzyme pattern $X$ in this study. One strain reacted with both protein $\mathrm{IA} / \mathrm{gk}$ and protein $I B / j$, which was confirmed by repeated experiments.

In the study reported here the dominance of WI strains was comparable with the findings of Danielsson et al from smaller Swedish towns. ${ }^{13}$ On the other hand, WII strains dominated in major Scandinavian towns. ${ }^{7}$ WIII strains are rare 
anywhere, ${ }^{71}$ as they were in this study. As WI strains are reported to occur more often in women than in men, ${ }^{14}$ the dominance of women in our study $(53 / 92)$ may be another explanation for the high incidence of WI strains. The occurrence of 12 serovars in our patients makes us think that the introduction of new strains is relatively common in this rather limited geographical area.

The gonococcal strains in this study were more resistant to doxycycline than those in the study by Bygdeman, ${ }^{15}$ whereas the correlations between susceptibility to doxycycline and serogroups were similar in the two studies.

The restriction enzyme technique may also be of diagnostic value. It was of interest to note that of the 15 band patterns examined by superimposed microdensitometer scanning, one band was found to be shared by all the clones examined. This band (size of fragments 1.45 kilobase pairs) could possibly represent a diagnostic marker, at least of neisserial infection. In fact, genetic tools for diagnostic purposes are already reported in gonococcal infection. ${ }^{16}$ If this band is specific for gonococci it could be used as a probe to identify gonococcal DNA by hybridisation techniques. Microdensitometer scanning might also be a potential tool for identifying restriction enzyme bands that are characteristic of a particular genotype. Such an approach would give us a possibility of constructing DNA probes that could be used to identify strains of a particular genotype by hybridisation techniques. Work is now in progress along these lines.

The combination of different markers in the studies of diplococci has been shown to give more epidemiological information than the use of only one of them. ${ }^{14}$ Thus the introduction of the restriction enzyme technique in epidemiological studies of both $N$ meningitidis ${ }^{4}$ and $N$ gonorrhoea $e^{1}$ has been shown to be of practical importance in the epidemiology of meningitis and gonorrhoea. Unfortunately, the restriction enzyme technique, like auxotyping, is expensive, time consuming, and requires highly qualified technicians. This novel tool has, however, been shown to be a good alternative to auxotyping and is of potential use in epidemiological studies of gonococci when combined with serological classification with specific monoclonal antibodies.
References

1. Falk ES, Bjorvatn B, Danielsson D, Kristiansen B-E, Melby K, Sørensen B. Restriction endonuclease fingerprinting of chromosomal DNA of Neisseria gonorrhoeae. Acta Pathol Microbiol Immunol Scand $[B]$ 1984;92:271-8.

2. Falk ES, Danielsson D, Bjorvatn B, et al. Phenotypic and genotypic characterization of penicillinase producing strains of Neisseria gonorrhoeae. Acta Pathol Microbiol Immunol Scand [B] 1985;93:91-7.

3. Falk ES, Danielsson D, Bjorvatn B, Melby K, Sørensen B, Kristiansen B-E. Genomic fingerprinting in the epidemiology of gonorrhoea. Acta Derm Venereol (Stockh) 1985;65:235-9.

4. Kristiansen B-E, Bjorvatn B, Lund V, Lindqvist B, Holten E. Differentiation of B15 strains of Neisseria meningitidis by DNA restriction endonuclease fingerprinting. J Infect Dis 1984;150:389-96.

5. Anonymous. Communicable disease report. Oslo, Norway: Statens Institutt for Folkehelse (SIFF), 1983.

6. Inman R, Schnös M, Simon L, Six EW, Walker D. Some morphological properties of P4 bacteriophage and P4 DNA. Virology 1971;47:67.

7. Bygdeman S, Danielsson D, Sandström E. Gonococcal W serogroups in Scandinavia. A study with polyclonal and monoclonal antibodies. Acta Pathol Microbiol Immunol Scand [B] 1983;91:293-305.

8. Sandström EG, Chen KCS, Buchanan TM. Serology of Neisseria gonorrhoeae: coagglutination serogroups WI and WII/WIII correspond to different outer membrane protein I molecules. Infect Immun 1982;38:462-70.

9. Tam WR, Buchanan TM, Sandström EG, et al. Serological classification of Neisseria gonorrhoeae with monoclonal antibodies. Infect Immun 1982;36:1042-53.

10. Ericsson HM, Sherris JC. Antibiotic sensitivity testing. Report of an international collaborative study. Acta Pathol Microbiol Immunol Scand [B] 1971;217 Suppl.

11. Bjorvatn B, Lund V, Kristiansen B-E, Korsnes L, Spanne O, Lindqvist B. Application of restriction endonuclease fingerprinting on chromosomal DNA of Neisseria meningitidis. $J$ Clin Microbiol 1984;19:763-5.

12. Kristiansen B-E, Sørensen B, Simonsen T, Spanne O, Lund V, Bjorvatn B. Isolates of Neisseria meningitidis from different sites in the same patient: phenotypic and genomic studies, with special reference to adherence, piliation, and DNA restriction endonuclease pattern. $J$ Infect Dis 1984;150:389-96.

13. Danielsson D, Bygdeman S, Kallings I. Epidemiology of gonorrhoea: serogroup, antibiotic susceptibility and auxotype patterns of consecutive gonococcal isolates from 10 different areas of Sweden. Scand J Infect Dis 1983;15:33-42.

14. Bygdeman S. Serological classification of Neisseria gonorrhoeae. Relation to antibiotic susceptibility and auxotypes. Epidemiological applications. Stockholm, Sweden: University of Stockholm, 1981. Thesis.

15. Bygdeman S. Antibiotic susceptibility of Neisseria gonorrhoeae in relation to serogroups. Acta Pathol Microbiol Scand [B] 1981;89:227-37.

16. Totten PA, Holmes KK, Handsfield HH, Knapp JS, Perine PL, Falkow S. DNA hybridization technique for the detection of Neisseria gonorrhoeae in men with urethritis. $J$ Infect Dis 1983;148:462-71. 